\title{
Blended Learning for Lifelong Learning: An Innovation for College Education Students
}

\author{
Ava Clare Marie O. Robles \\ College of Education, Mindanao State University, General Santos City, Philippines \\ Email: ching08robles@gmail.com
}

\begin{abstract}
With the fast developing and changing transport of technology, new trends and learning opportunities were ushered in the field of Education. This transformation restructures the teaching-learning operation. As a result, educators encounter different learning preferences of students due to the emerging learning needs brought by technology. Although many universities here and abroad recognize the potential of blended learning, there is still lack of implementation on how blended learning be planned, designed and applied.
\end{abstract}

In response to this need, an empirical study on the use of blended learning approach was conducted, which involved the mixing of face-to-face and online delivery methods. Thus, the main purpose of this paper was to find out the effect of blended learning (BL) approach on the students' performance in education subjects.

Additionally, this work presents instructional strategies on how to effectively integrate content, pedagogy and technology to enhance the teaching and learning of education courses. This provided the most effective and efficient learning experiences on both teachers and learners with its practical applications against retailed software which often burden many universities.

Finally, some implications on how to effectively blend pedagogy and technology, which inevitably lead to significant enhancement of the curriculum, were also discussed.

Index Terms - Blended Learning, Technology, Lifelong Learning

\section{INTRODUCTION}

Technology has greatly amplified the value of digital classroom resources of every institution. Typically, the Internet has altered the teaching-learning paradigm and brought challenges to all students, educators and school administrators. With the nearly ubiquitous access to the Internet, the promise of technology to enhance learning is greater than ever. Likewise, revolutionary developments in technology are bringing radical changes in the way learner gain information. Thus, classroom teachers need to provide students enriched learning opportunities and experiences, which replicate the skills of 21st century education. To meet this challenge, Blended Learning (BL) may be employed by teachers to promote meaningful and authentic learning.
Currently, several teachers are employing BL, which enable them to face challenges at the same time take advantage of the stimulating new learning opportunities that are now accessible. As a consequence, these educators are encouraged to develop their instructional competence by using blended learning, which they found to be effective, affordable, and cost effective. Other studies have likewise found that people choose BL for three reasons: enhanced pedagogy, better access and flexibility, and amplified cost-effectiveness [1].

BL is the organic integration of carefully selected, harmonizing face-to-face and online approaches [2]. It combines online delivery of educational content with the best features of classroom interaction and live instruction to personalize learning, permit solicitous reflection, and discriminate instruction from student to student across a diverse group of learners. Moreover, emerging models suggest that a big part of the future of education will involve blended learning as an approach to prepare students for future task. This BL approach combines the best elements of online and face-to-face learning. Regardless of the exact definition of blended learning, it is likely to surface as the predominant model of the future [3]. In fact, some previous research recommendations highlighted BL approach as effective undertaking, which an institution should adapt or employ.

With the incessant need to employ innovative approaches to draw out initiatives that can strengthen and weave face-to-face and online learning in MSU, a key recommendation is that $\mathrm{BL}$ be embark on MSU-College of Education.

To address the above need, an empirical study on BL as an innovative approach to build students' crucial skills for lifelong learning was undertaken. Hence, this paper aimed to find out the effect of the BL approach to students' performance in Ed 103. Specifically, it sought answers the following questions:

1. Is there a significant difference in the performance in Ed 103 of the control group and the experimental group before the experiment?

2. Is there a significant improvement in the academic performance in Ed 103 among students who did not undergo blended learning?

3. Is there a significant improvement in the academic performance in Ed 103 among students who underwent BL? 
4. Is there a significant difference between the performances of the control and experimental group in Ed 103 after the conduct of the experiment?

5. Based on the result of the study, how may BL be planned, designed and applied in order to effectively blend content, pedagogy and technology?

The experimental and control group consisted of 60 students who were randomly selected during the second semester of SY 2011-2012. Pretests were given to both groups before the experiment to determine their knowledge equivalence in Ed 103. Only the experimental group who underwent blended learning approach. In the experimental group, students were also asked to make their e-portfolio about their experience on blended learning. After all the topics included in the experiment were discussed, post test was given to both groups.

The following statistical treatments were employed: mean, standard deviation, t-test for dependent samples, and t-test for independent samples. Hypotheses were tested at the .05 level of significance.

\section{RELATED STUDIES ON BL}

This section accords with the various readings and studies, which have a significant bearing to the present study. In expanding and enriching 21 st century learning opportunities for students, offering teachers, new techniques for delivering other special academic programs, BL has become an acceptable and effective learning model. BL gives institutions a strategy for overcoming the barriers presented by time constraint, restricted resources, and financial pressures. It also gives teacher an innovative range of alternatives to craft an updated curriculum that meets the needs and preferences of digital natives to learn more successfully in their technology-infused environment [4]. BL orhybrid learning is defined as an approach that combines teaching methods, delivery methods, and media formats. It also refers to the integrated learning activities such as a mixture of online and face-to-face learning [5].

For better understanding of the study, Ed 103 is a course number of Assessment of Student Learning course. This course is design to equip future teachers with essential notion, development and relevance of assessment tools to improve the teaching-learning process. In concept, it deals with measurement and assessment of students' learning outcomes such as test construction and interpretation of test scores.

There are many reasons that an instructor might decide on BL over other learning options. Research conducted by[6] examined and identified the six reasons one might choose to design or use a BL system: the pedagogical sumptuousness, access to information, social interaction, cost-effectiveness and ease of revision.

A research done by [7] highlighted that BL is a practical framework that can be used to encapsulate a range of effective approaches to learning and teaching. It encourages the use of contemporary technologies to boost learning, and the development of flexible approaches to course design to enhance student engagement. Irrespective of any concerns over its definition, the use of the term BL has become widely accepted and is omnipresent in all forms of education and training [8]. This BL endeavors to purposefully integrate online and traditional learning in order to create an innovative approach with its own merits [9].

Additionally, [10] regarded BL as a set of learning facets that mixes various event-based activities, including conventional instructor-led training, synchronous online conferencing and asynchronous self-paced study. BL, however, is often a mix of traditional instructor-led training, synchronous online conferencing, asynchronous self-paced study, and structured on the-job training from an experienced teacher. Synchronous training involves interacting with a faculty member and other learners via the Web in real- time using technologies such as virtual classrooms and/or chat rooms. On the other hand, asynchronous enables learners to interact with their colleagues and faculty member at their own convenience; such as interacting through email [11].

In this study, course sites by Blackboard, which is a free learning management was utilized to engage students in online learning and share open education resources. For better understunding on the different concepts, a conceptual framework is shown on the following page together with the sample of teacher's course site in Ed 103. 


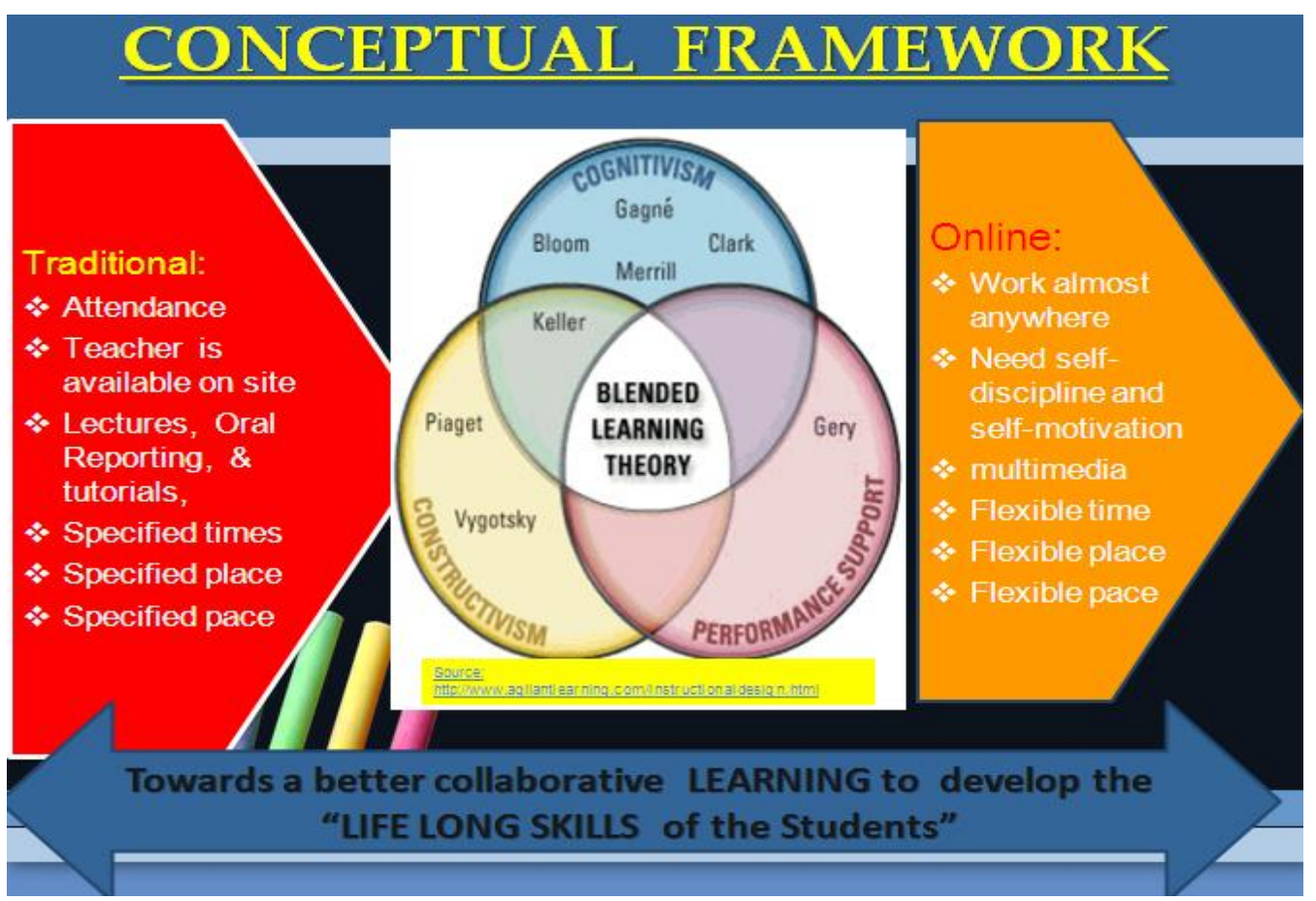

Figure 1. Conceptual Framework

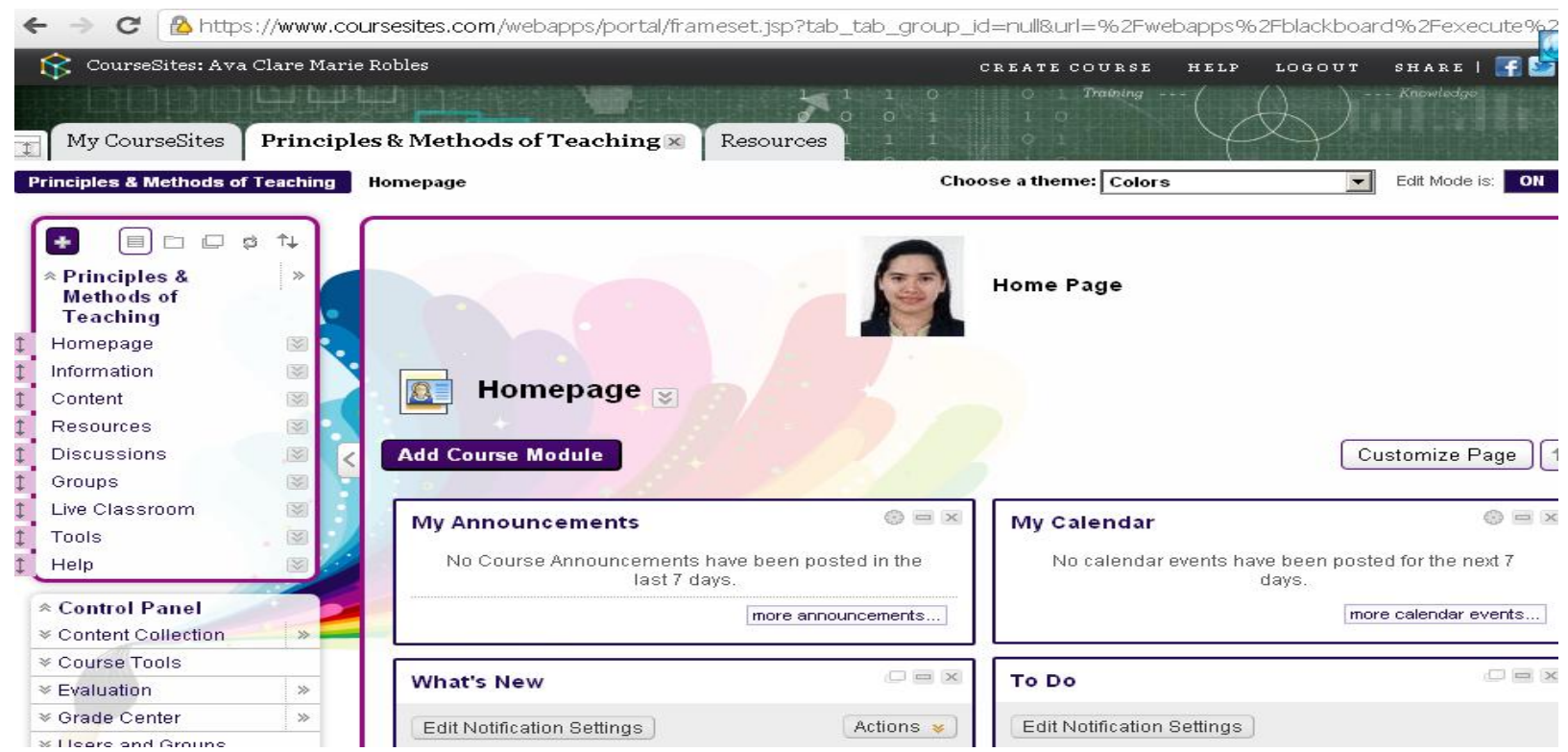

Figure 2. Screenshot Sample of Teacher's Course Site in Ed 103

\section{METHODOLOGY}

This study used the quasi-experimental design because there were only two groups involved in the study, the experimental group and the control group. The design is shown in the following paradigm:

$\begin{array}{llll}\text { Control Group } & \mathrm{O} 1 & -\mathrm{x} & \mathrm{O} 2 \\ \text { Experimental Group } & \mathrm{O} 3 & \mathrm{x} & \mathrm{O} 4 \\ \text { where: } & & & \end{array}$

O1 - refers to the pretest score of the control group. O3 - refers to the pretest score of the experimental group.

O1 - refers to the post test score of the control group. O4 - refers to the post test score of the experimental group.

$\mathrm{x}$ - refers to the conduct of BL approach in the experimental group.

$-\mathrm{x}-$ refers to the absence of BL in the control group. 


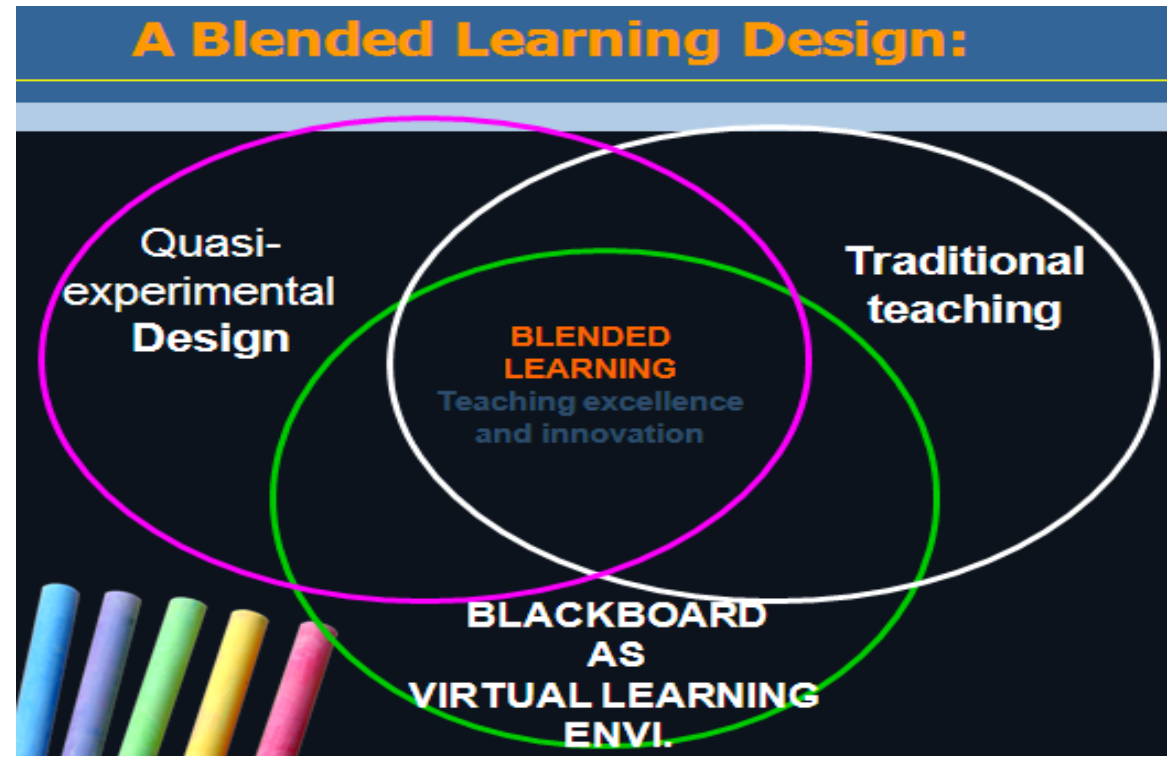

Figure 3. Blended Learning Design in Ed 103

\section{Procedures}

The subsequent steps were followed throughout the experimentation operation:

1. The experimental and control groups were randomly assigned. Prelim scores were taken into consideration in selecting the respondents and individual differences were neglected.

2. A presentation on "Blended Learning" with emphasis on E-portfolio making was explained to the students last November, 2011. The students in the experimental group were informed about the methods and way how this approach would be used.

3. Both groups were administered the online pretest in order to determine whether the experiment and control groups were equivalent in terms of research variables and preliminary information.

4. The research application was carried out three hours a week in a four-week period from November 15 , 2011 to December 22, 2011.

5. On January 10, 2012, the online post test was administered to the students.

The respondents of the study were sixty (60) BSED students in Mindanao State University, General Santos City, Philippines, who are enrolled in Assessment of Student Learning (Ed 103) Course, Academic Year 20112012.

The main instrument in the study was the pretest/post test in Ed 103 consisting of 30 items out of 100 items adopted from [12]. The reliability coefficient of the test was .0837. The test contained the following topics: Types of Measurement and their Differences; Establishing the Learning Targets; Analyzing and Using of Test Item Data;
Characteristics of a Good Test; and Rubrics, Portfolio \& Performance Based Assessment

\section{Data Gathering Procedure}

The researcher requested permission from the Dean of College of Education to allow her to conduct the study in MSU. Two groups of learners were utilized as the control group and the experimental group. The study was conducted within the months of November 2011 to January 2012, Academic Year 2011-2012.

The pretest was administered to both groups. After all the essential topics were covered, post test was given to both groups. The test scores were tallied and subjected to statistical analysis to determine the level of improvement of the two groups in Ed103 after undergoing blended learning approach.

\section{Statistical Treatment}

To determine if there was significant difference between the pretest scores of the experimental group and control group, t-test for independent samples was employed. Moreover, to determine whether there is significant difference in the pretest and post test scores of the experimental group, t-test for dependent samples was employed. To verify if there is a significant difference in the pretest and post test of the control group, t-test for dependent samples was used. Whether or not there is a significant difference in the mean gain score of experimental and control groups, the t-test for independent samples was utilized.

Despite the advancement in technology, Mindanao State University (MSU) is still experiencing limited information about how blended learning is done. Hence, this observation led the researcher to conduct a study on blended learning and its effectiveness in improving their performance in Ed 103. 


\section{FINDINGS AND ANALYSIS}

\section{A. Equivalence of the Control Group}

To determine whether the experimental group and the control group are equivalent before the experiment, $\mathrm{t}$-test for independent samples was used on their pretest scores. Table 1 reveals the result and the Experimental Group Before the Experiment.

Table 1 Equivalence of the Control Group and the Experimental Group before the Experiment

\begin{tabular}{|c|c|c|c|c|}
\hline Group & $\begin{array}{l}\text { Mean } \\
\text { Pretest }\end{array}$ & $\begin{array}{l}\text { t- } \\
\text { value }\end{array}$ & $\begin{array}{l}\mathrm{p}- \\
\text { value }\end{array}$ & Remarks \\
\hline $\begin{array}{l}\text { Control } \\
\text { Group }\end{array}$ & $\begin{array}{l}12.02 \\
13.38\end{array}$ & 0.582 & 0.562 & $\begin{array}{l}\text { There is } \\
\text { no } \\
\text { significant } \\
\text { difference }\end{array}$ \\
\hline $\begin{array}{c}\text { Experimental } \\
\text { Group }\end{array}$ & & & & \\
\hline
\end{tabular}

Based on Table 1, 60 students in the control group got a mean pretest of 12.02 while the 60 students in the experimental group got pretest mean score of 13.38. This yielded a difference of the means of 1.36.

Using t-test, the obtained t-value was .582 and p-value was.562. Since the p-value $>.05$, then the difference in the pretest scores was statistically not significant. This means that before the experiment, the control group and the experimental group were equivalent in terms of their knowledge in Ed 103. The experiment can be conducted since the two groups are equivalent.

This result led to the acceptance of the null hypothesis that there is no significant difference in the pretest scores between the control group and the experimental group.

\section{B. Performance of the Students in Ed 103 before the Experiment}

This study also described the students' performance in Ed 103 before the experiment. To do this, their percentage scores in each of the six topics in the pretest were computed. As shown in Table 2, 53.33\% of the control group obtained scores of 13 to 18 in the pretest. This is the highest percentage of the group, which is considered Fair performance. This is followed by $40 \%$ of the control group who obtained scores of 7 to 12 in the pretest. This is considered Poor performance in Ed 103.

Table 2 Performance of the Students in Ed 103 before the Experiment

\begin{tabular}{|c|c|c|c|c|}
\hline Topics & $\begin{array}{l}\text { Control Group } \\
\text { (Correct } \\
\text { Response in } \\
\text { terms of } \\
\text { Proportion) }\end{array}$ & $\%$ & $\begin{array}{c}\text { Experimental } \\
\text { Group (Correct } \\
\text { Response) }\end{array}$ & $\%$ \\
\hline Types of Measurement and their Differences & $10 / 30$ & $33 \%$ & $13 / 30$ & $43 \%$ \\
\hline Establishing the Learning Targets & $8 / 30$ & $27 \%$ & $7 / 30$ & $23 \%$ \\
\hline Analyzing And Using Of Test Item Data & $4 / 30$ & $40 \%$ & $6 / 30$ & $20 \%$ \\
\hline Characteristics Of A Good Test & $9 / 30$ & $30 \%$ & $10 / 30$ & $33 \%$ \\
\hline Rubrics, Portfolio \& Performance Based Assessment & $11 / 30$ & $37 \%$ & $12 / 30$ & $40 \%$ \\
\hline Educational Statistics & $6 / 30$ & $20 \%$ & $5 / 30$ & $17 \%$ \\
\hline
\end{tabular}

Table 3 Difference in the Performance of the Control Group

\begin{tabular}{|c|l|l|l|l|}
\hline Group & $\begin{array}{l}\text { Mean } \\
\text { Pretest }\end{array}$ & $\begin{array}{l}\mathrm{t}- \\
\text { value }\end{array}$ & $\begin{array}{l}\mathrm{p} \text { - } \\
\text { value }\end{array}$ & Remarks \\
\hline Pretest & 12.02 & 0.846 & 0.510 & $\begin{array}{c}\text { There is } \\
\text { no } \\
\text { significant } \\
\text { difference }\end{array}$ \\
$\begin{array}{c}\text { Post } \\
\text { Test }\end{array}$ & 12.37 & & \\
\hline \multicolumn{2}{|l}{ Mean Difference : 0.353} & & \\
\hline
\end{tabular}

\section{Performance of the Control Group}

The control group consisting of 60 students in Ed 103 did not undergo blended learning. To determine if the performance of the control group improved significantly in the identified topics in Ed 103 even without blended learning, t-test for dependent samples was used between the pretest and post-test scores of the 60 students in the control group. Table 3 shows the result.

Using t-test for dependent samples, the obtained $\mathrm{t}$ value was 0.846 and $p$-value of 0.510 . Since the $p$ value $>.05$, then there is no significant difference between the pretest and post-test scores of students in the control group. 
This means that without blended learning, the control group did not improve its performance significantly. The difference in the post-test and pretest was very small indicating that the students learned very minimal in $\mathrm{Ed}$ 103 when their classes were not employed with blended learning approach.

\section{Performance of the Experimental Group}

The experimental group consisting of 60 students in $\mathrm{Ed}$ 103 underwent blended learning. To determine if the performance of the experimental group significantly improved when they underwent blended learning, t-test for dependent samples was used between the pretest and post-test scores of the experimental group. Table 4 shows the result.

Table 4 Difference in the Performance of the Experimental Group

\begin{tabular}{|c|l|l|l|l|}
\hline Variable & $\begin{array}{l}\text { Mean } \\
\text { Pretest }\end{array}$ & $\begin{array}{l}\mathrm{t}- \\
\text { value }\end{array}$ & $\begin{array}{l}\mathrm{p} \text { - } \\
\text { value }\end{array}$ & Remarks \\
\hline $\begin{array}{c}\text { Pretest } \\
\text { Scores }\end{array}$ & 13.38 & 4.935 & 0.000 & $\begin{array}{l}\text { There is a } \\
\text { significant } \\
\text { difference }\end{array}$ \\
$\begin{array}{c}\text { Posttest } \\
\text { Scores }\end{array}$ & 15.98 & & & \\
\hline Mean Difference : 2.6 & & & \\
\hline
\end{tabular}

Based on Table 4, the pretest scores of the experimental group got a mean of 13.383 while the posttest scores got a mean of 15.983. This yielded a mean difference of 2.6. Using t-test for dependent samples, the obtained t-value was 4.935 and p-value of 0.000 . Since the $\mathrm{p}$-value $<.05$, then there was a significant difference between the pretest and post-test scores of students in the experimental group.

This means that when the students in the experimental group underwent blended learning in Ed 103, their performance significantly improved. This is shown by the increase in their post-test scores. A possible explanation for this is that blended learning helped increase students' interest in the subject, which contributed to the increase of its performance in the post-test.

\section{E. Effectiveness of Conducting Blended Learning Approach}

To determine whether blended learning has been effective in improving the performance in Ed 103 as compared to the traditional method of teaching without blended learning approach, t-test for independent samples was used between the mean gain scores of the experimental group and the control group. Gain score is simply the difference between the post-test and the pretest scores. Table 5 reveals the result.
Table 5 Difference in the Performance of the Control Group and the Experimental Group

\begin{tabular}{|c|c|c|l|l|}
\hline $\begin{array}{l}\text { Variable } \\
\text { (Gain Score) }\end{array}$ & $\begin{array}{l}\text { Mean } \\
\text { Pretest }\end{array}$ & $\begin{array}{l}\mathrm{t}- \\
\text { value }\end{array}$ & $\begin{array}{l}\mathrm{p} \text { - } \\
\text { value }\end{array}$ & Remarks \\
\hline $\begin{array}{c}\text { Control } \\
\text { Group }\end{array}$ & 0.353 & 4.935 & 0.000 & $\begin{array}{c}\text { There is a } \\
\text { significant } \\
\text { difference }\end{array}$ \\
$\begin{array}{c}\text { Experimental } \\
\text { Group }\end{array}$ & 2.6 & & \\
\hline \multicolumn{2}{|c|}{ Mean Difference : 2.247} & & & \\
\hline
\end{tabular}

Using t-test, the obtained value was 4.935 and $\mathrm{p}$-value of 0.000 . Since $\mathrm{p}$-value $<.05$, then there was a significant difference in the mean gain scores of the control group and experimental group. This means that the performance of the experimental group who underwent blended learning approach improved significantly better than the control group who did not undergo blended learning. This is revealed by the higher gain scores obtained by those who underwent blended learning. This result led to the conclusion that blended learning helps significantly in improving the students' performance in Ed 103. Hence, blended learning is a positive approach that increases students' performance.

\section{RESULTS OF BLENDED LEARNING \& ITS IMPLICATIONS}

The students who underwent blended learning made their blogs as their e-portfolio during their blended learning sessions. The majority of students found e-portfolio interesting and helpful because it encouraged them to publish their reflections and feelings toward their blended learning in Ed103. The lessons learned were noted by the instructor so that this served as basis on how may BL be planned, designed and applied in order to effectively blend content, pedagogy and technology in Ed103.

A wider implication is that universities need to utilize blended learning to improve students' performance. These findings should be reviewed in consideration of study limitations, this research implies that blended learning indeed enhances Ed 103 course.

When preparing BL for students, it is necessary that these key questions are answered: (1) what are your course objectives? (2) What are your students' learning preferences and background in technology?; (3) What free learning management system do you wish to employ (e.g. blackboard or Moodle )?

On the other hand, in designing effective BL, the instructor must: (1) determine the application model he wants to employ (skill/attitude/competency driven model); (2) Identify his course components (Syllabus, \& Protocols / Introduction/Possible links to different websites \& interaction/ Assessment). Below is the flow chart of its design. 


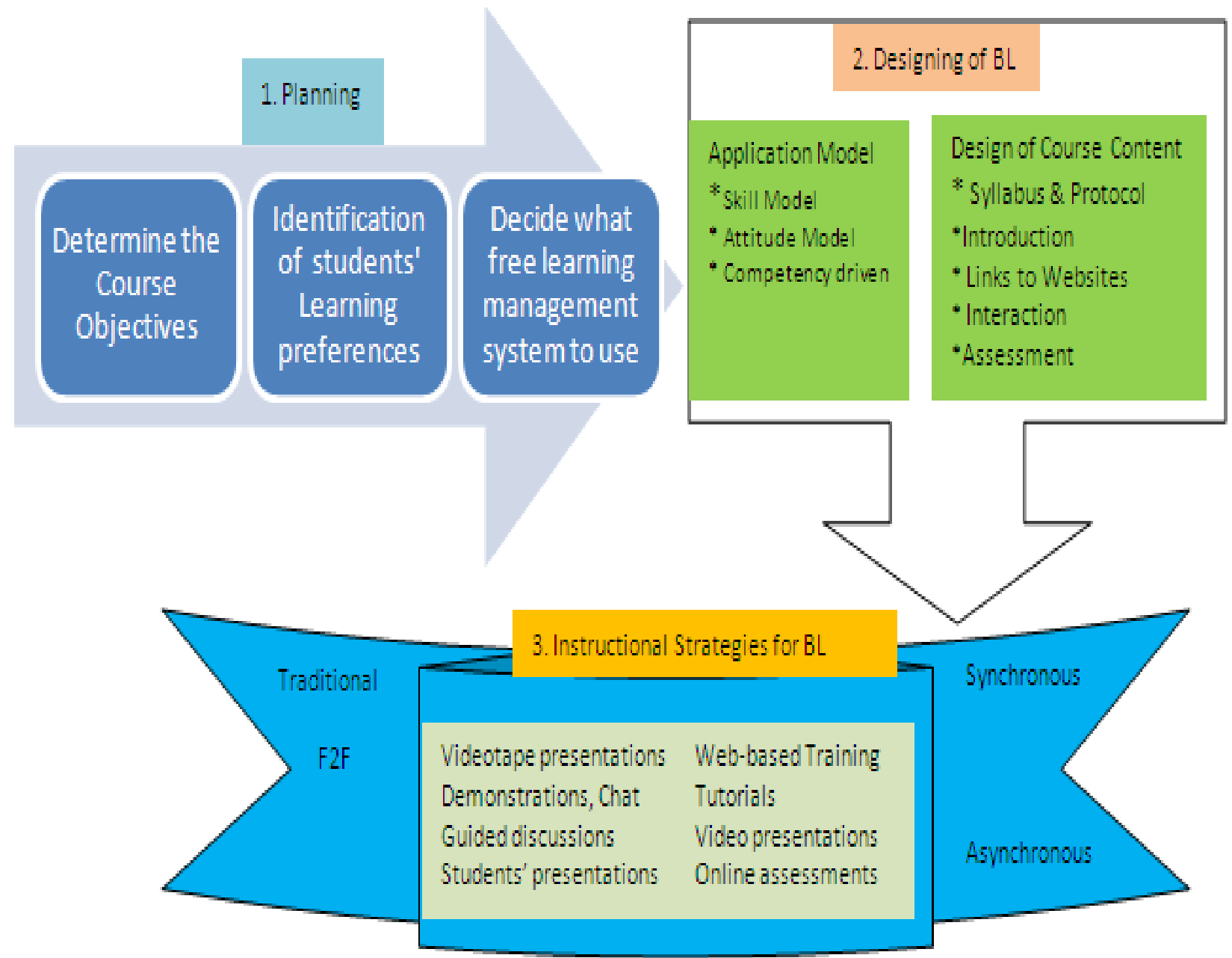

Figure 4. The Flow of the Design Process

\section{CONCLUSION AND RECOMMENDATION}

In the light of the findings, the following conclusions were made:

1. There is no significant difference in the performance between control group and experimental group before the experiment was conducted. This implies that the two groups are equivalent in terms of their knowledge in Ed 103.

2. Students who did not undergo blended learning did not show significant improvement in Ed 103;

3. Students who undergo blended learning show significant improvement in Ed 103. This means that Blended learning is a helpful approach for college students to improve their academic performance;

4. There is a significant difference between the performances of the control and experimental group in Ed 103 after the conduct of the experiment. This means that the performance of the experimental group who underwent blended learning approach improved significantly better than the control group who did not undergo blended learning. The main reason for this is that many college students find blended learning interesting.

Nowadays, there are varieties of blended learning models, but it has no definite best approach. Accordingly, planning, designing and the application of BL are big challenges to educators. However, one may consider it as best BL model if and only if it works best for students and teachers and that it addresses their specific needs at the time. Moreover, it has to be flexible enough to provide a wide range of students' learning needs and opportunities.

In view of the findings and conclusion of the study, it is recommended that blended learning be utilized by faculty members in teaching education subjects. However, despite its importance, this study's limitations are apparent. BL needs effective planning and upgrading for educators to address critical issues such as establishing appropriate assessments and rubrics. Equally important is the technological expertise of both teachers and students. This innovation recommends that teachers must learn 
how to effectively design their BL activities. With this, the author highly recommends further research along this type of innovation.

\section{ACKNOWLEDGMENT}

The author wishes to thank Professor Thelma Pagunsan, Dean of Bachelor of Secondary Department, College of Education, Mindanao State University, for her undying support to successfully complete this endeavor. Moreover, she wishes to thank all Bachelor of Secondary Students in Education 103 who had been very supportive and efficient during the conduct of this study.

\section{REFERENCES}

[1] Graham, C. R.; Allen, S. \& Ure, D. (2005). "Benefits and challenges of BL environments" In M. Khosrow-Pour (Ed.), Encyclopedia of information science and technology (pp. 253-259). Hershey, PA: Idea Group.

[2] Garrison, D. R. \& Vaughan, N. (2008). Blended learning in higher education: Framework, principles, and guidelines. San Francisco, CA: John Wiley \& Sons.

[3] Watson, John(2011). Blended Learning: The Convergence of Online and Face-to-Face Education. Retrieved on 8 Oct 2011 from http://www.inacol.org/research/promisingpractices/N ACOL_PP-BlendedLearning-lr.pdf.

[4] Pokuaa, Juanita (2011).Blending The Traditional Face-To-Face Learning With Instructional Technology Published Thesis from Department of Computer Engineering, Kwame Nkrumah University of Science and Technology. Retrieved on December 2011

from http://dspace.knust.edu.gh:8080/jspui/bitstream/1234 56789/516/1/fultxt.pdf

[5] Moebs, S. and Weibelzahl, S. (2006). Towards a good mix in blended learning for small and mediumsized enterprises -Outline of a Delphi Study.
Proceedings of the Workshop on Blended Learning and SMEs held in conjunction with the 1st European Conference on Technology Enhanced Learning Crete, Greece, pp 1-6.

[6] Osguthorpe, R. T. \& Graham, C. R. (2003). "BL systems: Definitions and directions" Quarterly Review of Distance Education, 4(3), 227-234.

[7] Queensland University of Technology (2011). Protocols: Blended Learning. Retrieved on 11 September 2011 from http://www.ltu.qut.edu.au/curriculum/documents/PL C_blended_learning.pdf

[8] Smythe , Michael(2011). Blended learning: A transformative process? Retrieved on December 12,2011 from http://akoaotearoa.ac.nz/download/ng/file/group3740/smythe---blended-learning-a-transformativeprocess.pdf.

[9] Allen, I. E., Seaman, J\& Garrett R. (2007). Blending In: The extent and Promise of Blended Education in the United States. Needham, MA: The Sloan Consortium, Retrieved May 23, 2009, from http://www.sloanc.org/publications/survey/pdf/Blend ing_In.pdf.

[10] Singh, H. (2003). Building effective blended learning program, Educational Technology, 43(6), pp 51

[11] Hrastinski, S. (2008). "Asynchronous and Synchronous E-learning” EDUCAUSE Quarterly Vol. 31

[12] Concepcion et.al. (2011) Licensure Examination for Teacher (LET) NCBTS Oriented.2011 Edition LET Reviewer. Sampaloc, Manila, Philippines.

Ava Clare Marie O. Robles is an Associate Professor IV in Mindanao State University, Philippines. She had been an International paper presenter in Thailand and Malaysia, authored three books and a Graduate School professor in Mindanao State University and Notre Dame of Marbel University. 